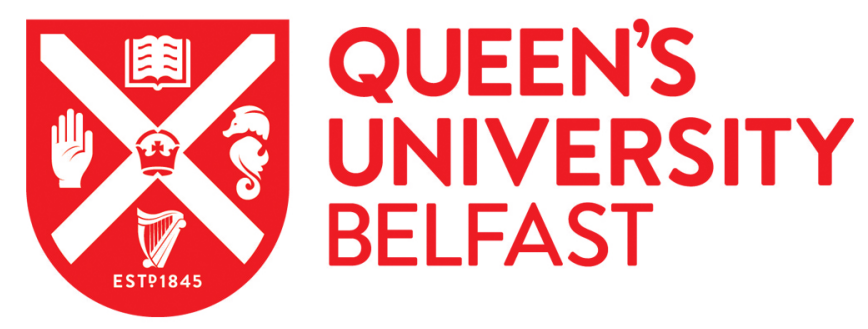

\title{
Shadow policing: the boundaries of community-based 'policing' in Northern Ireland
}

Topping, J., \& Byrne, J. (2016). Shadow policing: the boundaries of community-based 'policing' in Northern Ireland. Policing and Society, 26(5), 522-543. https://doi.org/10.1080/10439463.2014.989152

Published in:

Policing and Society

Document Version:

Peer reviewed version

Queen's University Belfast - Research Portal:

Link to publication record in Queen's University Belfast Research Portal

Publisher rights

(C) 2014 Informa UK Limited, trading as Taylor \& Francis Group

This is an Accepted Manuscript of an article published by Taylor \& Francis in Policing and Society on 16 Dec 2014, available online: http://www.tandfonline.com/doi/full/10.1080/10439463.2014.989152

\section{General rights}

Copyright for the publications made accessible via the Queen's University Belfast Research Portal is retained by the author(s) and / or other copyright owners and it is a condition of accessing these publications that users recognise and abide by the legal requirements associated with these rights.

Take down policy

The Research Portal is Queen's institutional repository that provides access to Queen's research output. Every effort has been made to ensure that content in the Research Portal does not infringe any person's rights, or applicable UK laws. If you discover content in the Research Portal that you believe breaches copyright or violates any law, please contact openaccess@qub.ac.uk. 
'Shadow Policing': Security governance and the parameters of 'policing' Northern Ireland 


\title{
'Shadow Policing': Security Governance and the Parameters of 'Policing' Northern Ireland
}

\begin{abstract}
Grounded in governance of security theory, this article seeks to provide a structural and operational analysis of policing beyond the police in Northern Ireland. While the polity enjoys relatively low levels of 'officially' recorded crime as part of its postconflict status, little empirical analysis exists as to the epistemological roots of security production outside that of the Police Service of Northern Ireland (PSNI). The article aims to establish that beyond more prominent security analyses related to paramilitary 'policing', the country is in fact replete with a substantial reservoir of legitimate civil society policing which contributes to policing, community safety and quality of life issues. While such non-state policing at the level of locale was recognised by the Independent Commission for Policing (ICP), structured understandings have rarely permeated governmental or academic discourse beyond anecdotal contentions. Thus, the article provides an empirical assessment of the complex, non-state policing landscape beyond the formal state apparatus; examines definitions and rationalities for such community-based security governance; and explores issues related to co-opting such non-state security 'otherness' into more formal relations with the state.
\end{abstract}

Key words: governance of security; policing; security; community; Northern Ireland; 


\section{Shadow Policing: Security Governance and the \\ Parameters of Safety in Northern Ireland}

\section{Introduction}

Almost without exception, dominant narratives of policing, safety and security associated with Northern Ireland's recent transformations have centred on the progress towards 'normal' policing by the Police Service of Northern Ireland (PSNI) (Ellison 2007; Topping 2008a). With changes to the formal state policing apparatus having acted as 'meta bargaining' as part of the transition from conflict to peace, it may be contended that structural re-alignments to policing started under the Independent Commission for Policing in Northern Ireland (ICP 1999) have by-inlarge, been completed (Campbell et al. 2003; Topping 2008b). Indeed, the ICP was set up as part of the 1998 Belfast Agreement political negotiations in the country, with a mandate to resolve the issue of policing which for many, lay at the very heart of the conflict (O’Rawe 2003).

Undoubtedly, current evidence highlights contention as to the success (or otherwise) of PSNI's ability to deliver community policing (or Policing with the Community under the rubric of the ICP) as central to its more 'normalised' service (CJINI 2012); notwithstanding the persistence of a severe dissident terrorist threat, the potential for civil disorder, and legacy issues (Byrne and Monaghan 2008; Ellison and O’Rawe 2010; Frampton 2011; Lundy 2011; McDonald, 2012; Topping and Byrne 2012a). But for the majority of the population, the imperative of fully inclusive, shared police governance between former Loyalist and Republican protagonists has been realised through policing 'having been given back to the people' - notably through some of the most robust policing oversight and accountability structures anywhere in the world (Bayley 2008; Mulcahy 2006; Office of the Oversight Commissioner 2007).

However, the intention here is not to recount nor assess the parameters of policing in Northern Ireland through the lens of police-organisational change; nor consider policing from the perspective of well rehearsed debates surrounding summary, paramilitary 'justice' as a form of social control during the conflict (Knox 2002; Hayes and McAllister 2005). Rather, this paper seeks to define safety and 
security through the existence of what the authors term 'shadow policing' - as a distinct form of latent, non-state and networked form of security governance across the country which contributes to the post-conflict peace and the relatively safe nature of the polity (Brogden, 2000). This may also be viewed as an alternative narrative to that of exclusive police 'ownership' of Northern Ireland's 'criminological netherworld', epitomised through its position as Europe's low crime comparator in spite of the recent history of protracted, internal armed conflict (Ellison and Mulcahy 2001; Van Dyk et al. 1990; Lyness et al. 2004; PSNI 2012). And importantly, beyond the 'official' criminological picture, it is contended that a significant gap in academic or policy debate has been a sufficient interrogation of the dynamics underpinning this production of policing, with the presumption of causal security relations having remained firmly with the police (Topping and Byrne 2012a).

Grounded in governance of security theory, the remainder of the paper seeks to frame and analyse policing (in its broadest sense) outside that of the state (Shearing and Wood 2003; Martin 2012). From the outset, it is important to note the paper deliberately excludes both policing associated violent, extra-juridical 'justice' by paramilitary actors; along with modes of activity grounded in more formal state origins, such as neighbourhood watch (Loader and Walker 2001; Topping, 2013). Thus, as part of reconnecting 'alternative' sources of policing to the etiology of security production (O’Mahony et al. 2000; McEvoy et al. 2002), such non-state security governance may be imagined as encompassing

'any institutional, organisational, communal or individual agents or nodes...that are interconnected in order to authorise and/or provide security to the benefit of internal or external stakeholders' (Dupont 2004:78).

The paper will further seek to analyse that which constitutes non-state security governance, or 'shadow policing' in Northern Ireland; while defining the delivery of policing and security from the perspective of those actors and organisations. And finally, the paper will also propose avenues for cooperation between such actors and the PSNI as part of acknowledging the reality of 'shadow policing' which exists - as a hybrid of what Topping (2008b) has termed 'community governance policing'. Indeed, the imperative of this approach has been captured by Baker (2002:31) who notes that policing and security are not shaped entirely by national public agendas, but by consumers, or the public. And where non-state actors and agencies bypass the 
formal state policing apparatus, the state's role in security provision must therefore be re-examined.

\section{Methodology}

The empirical data for this paper draws upon extensive qualitative evidence spanning the period from 2007-2012 concerned with the delivery of non-state policing in Northern Ireland. With kind permission, the majority of the data is drawn from interviews and case studies carried out by the authors as part of a research study for the Belfast Conflict Resolution Consortium (BCRC) in 2011 to examine a decade of community safety policy and practice in Northern Ireland (XXXX). The BCRC is part of the PEACE III Programme under the Special EU Programmes Body and provides citywide, cross-community partnership working between representative Loyalist and Republican organisations to assist conflict transformation across Belfast's interfaces and divided communities. As part of the longitudinal approach, this BCRC research is further supplemented through drawing upon complimentary policing research by one of the authors (XXXX).

In this regard, the paper is based on a total of thirty-six semi-structured interviews with representatives and organisations across Loyalist and Republican communities (mainly) in the Greater Belfast area; along with four case studies of community-based organisations who deliver either conflict management programmes or policing interventions at a local level. Of the interviews, sixteen were drawn from both from Loyalist and Republican areas, with four interviews derived from organisations representing neutral or 'cross-community' affiliations. Looking to the four case studies, they comprise data which detailed the the activities of: a Loyalist/Unionist community support programme for former paramilitary members; a Republican/Nationalist community safety forum working outside formal state community safety parameters; a cross-community partnership dealing with issues related to interface violence and tensions; and a summer intervention scheme to provide diversions for young people from the criminal justice system.

Thus, the present study draws uniquely upon the activity of those auspices directly involved in security governance in the country - as the first empirical interrogation of non-state policing provision in beyond more generic contentions (Office of the Oversight Commissioner 2007; Kempa and Shearing 2002). However, 
for the purpose of the current analysis, the authors concentrate solely upon the nature of non-state policing from the perspective of the auspices and providers themselves, rather than considering views from a police or statutory standpoint. Furthermore, the intention of the paper is not to provide a comparative analysis of non-state policing between Loyalist and Republican communities. Rather, the present research aims to capture the nature of those policing contributions as part of a baseline assessment of such activity.

While the extent of research 'generalisability' across the country may limited (Mason 1996), the literature points more generally to the fact that policing issues within the Loyalist and Republican sample areas have a resonance with the wider communities they represent, although broadly restricted 'to urban rather than the more rural and isolated areas of the country, often sheltered from the more damaging effects of the conflict' (Topping 2008b:780). And beyond traditionally polemic Loyalist/Unionist and Nationalist/Republican comparisons, the current research is about providing a more nuanced interpretation of the diverging interests and rationalities which underpin non-state security governance activity in comparison with policing as delivered by PSNI; and locate this within the context of their existence (Loader and Walker 2001).

As the authors would further argue, part of the current empirical gap in such understanding lies with the sheer lack of governmental, policy or academic research space afforded to capturing non-state policing provision in the country. In reference to the former, this has been 'reflective of a mindset which fears genuine community involvement and ownership in the process of justice' (McEvoy et al. 2002:197) especially where many of those involved in local security arrangements are themselves former combatants or protagonists in the conflict (Shirlow et al. 2005; Shirlow and Murtagh 2006; Dwyer 2012). Yet on a more pragmatic level, such limited knowledge is due to the fact there has simply been no systematic 'mapping' of existing auspices and providers of security in Northern Ireland; nor an assessment of their governing sensibilities and practices and the issues this poses for policing arrangements (Wood 2004). The current methodological approach therefore aims to provide a 'grand tour' of this issue, with the explicit intention to open up understandings, rather than definitively capture, the fact that PSNI are not the only auspice capable of providing a viable 'security good' in the country (Grabosky 1992; Loader and Walker 2006; Shearing 2006; Undheim 2003). 


\section{The context of non-state policing in Northern Ireland}

One of the key issues to consider as part of beginning to imagine non-state security governance in Northern Ireland is with the conceptual policing framework. It is important to note that security, nor its governance, is a neutral concept as part of the socio-political landscape which has underpinned policing over the past thirty years in the country (O’Rawe 2003). While the paper does not seek to recount the historical antecedents of (necessary) police reform in the country, the state police - and by extension security - have been symbolic of the normative ordering of Northern Ireland's (still) divided society (Ellison 2007; Ellison and Martin 2000; Mulcahy 2006; Shirlow and Murtagh 2006). To this extent, policing remains inextricably linked to wider debates about the processes of ensuring security is governed 'in ways that promote 'public goods' in accordance with 'public interests' (Shearing and Wood 2003:205).

Examing the reforms to policing under the ICP, on the one hand they created a police-organisational change process, described as one of the most complex blueprints for police reform anywhere in the world (OOC 2006). And in relation to the

'public good' of policing in the country, such reforms were part of 'an end to the incremental and politically nuanced 'tinkering' to policing, and the beginning of a substantive, inclusive and permanently acceptable change process...' (Topping 2008a:377-8).

Yet on the other hand, the effect of the necessary ICP reforms, in spite of Shearing's more radical vision, was to entrench the Western democratic tradition of clinging 'tenaciously to the belief that the contemporary array of policing institutions is the only one capable...' (Burris 2004 cited in Shearing 2006:13). In this respect, the organisational and structural changes associated with the ICP's first 'stream' of physical reforms trumped over the more radical, second 'stream' related to the governance of security - described by O’Mahony et al. (2000) as part of a 'missed chance' to embrace alternative community security capacities (Topping 2008a; 2008b).

Further police-organisational limitations to wider policing considerations in the post-ICP era may be observed through the reduction of the ICP's broader policing language to that of technocratic, operational definitions of police activity (Belfast Telegraph 2012; Brunger 2011). With significant socio-political capital generated from PSNI's position as one of the most accountable, overseen police services 
anywhere in the world such police-centric, bureaucratic inertia has become the definition of policing delivery itself (Bayley 2008; Ellison 2007). Thus, chances to conceive policing in language other than that set by the policing institutions have remained limited - especially where non-traditional policing discourse challenges the orthodoxy of PSNI's organisational 'expertise' on crime control (Johnston and Shearing 2003; Topping and Byrne 2012a). However, beyond such general issues of police-organisational centrism, within the context of how security is governed there exists a specific meaning in terms of policing delivery as a power relation in the country.

Indeed, the combination of political symbolism to the reform process; the retention of one of the highest police-to-population ratios in the Western world; and the lowest crime figures in 14 year, have all cemented PSNI's operational prowess in policing and security matters (Topping and Byrne 2012b). The issue for PSNI has therefore been their inability to officially 'accept' that modes of policing other than their own have contributed to, or are a necessary part of, the security status quo - at least in the public eye. And while community policing has been PSNI's dominant narrative as part of policing with communities across the country, engagement with security 'others' as part of this power dynamic, remains taboo (Dupont 2004).

To some extent, it is possible to observe the rationale for PSNI resisting what may be viewed as challenging or competing loci of power - especially when set against the destablising potential of challenges to PSNI authority and all they represent. Yet on the other hand, it has been well documented that non-state, community-based security provision continues to be a significant 'player' as part of the wider spectrum of policing in the country (Jarman 2002; 2006; OOC 2007; Topping 2008b; Topping and Byrne 2012a).

The present argument is therefore about moving past such transitional politics of police change, contest and ownership characteristic of the post-ICP era; and to consider 'a radically different conception of social order in which consideration is given to the conditions under which groups are prepared to cooperate...' (Crawford 1995:122). This is especially pressing when auspices of non-state security governance in Northern Ireland still tend 'to be judged illegitimate in terms of the very Westphalian ideal that they are moving beyond' (Kempa and Shearing 2002:30).

As part of contextualising non-state security governance in the country, to some extent broad sociological explanations have been set forth to consider, for 
example, the country's resilience to crime in comparison with other post-conflict societies (Altebeker 2005). Through a Durkheimian school of 'solidarity in conflict', detailed accounts of close-knit communities, vibrant civil society and 'grapevine' community networks have all been used to explicate (mainly) urban, working-class Loyalist and Republic community resistance to the vagaries of crime notwithstanding the actual and potential deterrent effects of brutal paramilitary 'back alley justice' meted out at local levels (Shaw and Shearing 1998; Brewer 2001; Brogden 2000; Morrisey and Pease 1982; Monaghan 2004; NICVA 2005; Topping and Byrne 2012b). Furthermore, significant alienation of (mainly) Republican/Nationalist communities from engagement with the formal state police throughout the conflict and post-conflict phases of recent history add weight to the fact dynamics beyond state police intervention mediate the country's criminological narrative (Byrne and Monaghan 2008; Ryder 1997; Ellison and Mulchay 2001; Ellison 2000).

Though more significantly, and for the purposes of the present argument, as noted by one of the former ICP commissioners, Clifford Shearing, what belies this rather amorphous picture of security production are:

'networks of policing nodes - as agencies, groups and collectives...outside the public sector that directly participate in the process of policing...[as] a fact of life’ (Shearing 2000:388).

Indeed, a key aim of this paper is to take forward the thinking of the body set up to oversee the implementation of the ICP recommendations, the Office of the Oversight Commissioner (OOC), who stated in their final report that the country's policing institutions should be alert to the contributions of well-intentioned, non-violent community and voluntary organisations and individuals (Kempa and Shearing 2002; Topping 2008a; 2008b; CJINI 2006). 


\section{Defining shadow policing}

In an attempt to define the reality of that which comprises 'shadow policing' in Northern Ireland, an initial point of reference lies with the perspective taken on governance of security itself. Martin (2012) argues that an overly simplistic analysis of police-organisational diversification within Western policing traditions has dominated thought, whereby the 'solid state' technologies of the public police are gradually giving way to more malleable forms of security as part of society's growing security needs (Garland 2001; Hughes 2007; Zedner 2009).

In view of the unique post-conflict environment from which such security 'otherness' has emerged in the country, is therefore important to extricate analysis from the ‘trap' of resource/demand comparisons. Indeed, from the research non-state policing capacities in the country are comprised of:

'a very diverse group of people...some very politically motivated groups, some very socially motivated groups - it's a complete mixed bag. And their level of engagement with the police will vary quite widely' (community respondent).

Though by the same token, it is important from the outset not to develop overly 'cosy' or 'wholesome' conceptions about the capacity and ability of non-state actors to deliver policing and security within any constitutive or fundamental sense of the term - not least because it would be naïve to assume otherwise because of the country's (paramilitary) history of 'dark social capital' (Lea 2002; Loader and Walker 2006; Putzel 1997; Zedner 2009). However, to simply 'recode' the delivery of security as acceptable or unacceptable (Rose 1996) - either set against neoliberal police 'standards' or political viability - belies the complexity of security governance as conceived and delivered in Northern Ireland (Johnston and Shearing 2003). Indeed, the post-conflict focus upon PSNI alone has created a 'security fallacy' whereby 'the public believe that the government possess the ability to control the crime rate and that a failure to do so represents a lack of service delivery' (Leggett 2003 cited in Marks and Goldsmith 2006:157). In this regard, it was an apt comment by a community-based respondent that:

'We're no alternative to the PSNI. What we are is a response to a lack of policing in our own areas. So we aren't out trying to be the '[named area] cops'. It isn't like that at all. There was stuff [crime] going on, it wasn't being policed, and it needed to be policed. So we developed a community response to that'. 
At this point, the authors argue that the policing landscape in the country should therefore be viewed as a collection of 'territories' of ‘security administration'. Thus, it allows for the rejection of any one particular perspective on the delivery of policing and accepting, in a Foucauldian sense, that the power for policing comes from everywhere - the harnessing of which has the potential to deepen the democratic, common 'good' security (Shearing 2006). This may be observed in regard to one respondent whereby:

'there's so many different permutations and calculations, it really is a minefield at times who you're dealing with and where they sit. But in all honesty, they're all going towards the same objective at the end of the day they all want a better place and a safer place for all the community to live in'

Though beyond the conceptual, the contextual circumstances out of which non-state security governance has emerged are equally important in helping to supply a definition of 'shadow policing'. Here, security governance at a local level may be imagined as a 'point' on a wider spectrum of civil society organising in the country or its civic 'hyper-organisation’ (Bayley 2008). Indeed, such civil society energy across a range of domains including health, education, politics, advocacy and human rights 'has been inextricably linked with, and interconnected with, the political situation' (Acheson et al. 2004:41) - related to wider societal coping mechanisms for the pressures of internecine, armed conflict and sectarian division over nearly four decades.

More specifically, and developing out of what may be termed a policing and security 'vacuum', the historical separation of mainly working-class Republican and Nationalist communities from state police intervention has generated a sense of 'security liminality' in which the normal processes of Peelian policing simply do not work (Byrne and Monaghan 2008; Mulcahy 2006). Thus, it is within this liminal 'space' in which a variety of actors beyond the state have existed (and continue to exist) as part of the complex policing landscape. And somewhere in between, it is Morrow (2006:73) who succinctly states that:

'where the state could not provide protection, which was the starting point for many Catholics and Nationalists and could easily emerge for less well protected working class Protestant communities...there was an enormous reservoir of understanding for extra state [policing]'. 
Therefore, it is this state security and policing liminality combined with (locally) viable and willing actors to fill policing requirements which is of interest. Because where such activity occurs, by default it falls outside standard legal, procedural and regulatory rules to which state organisations are subject, creating alternative rules of operation, informed by the local circumstance and distance from the state police (Johnston and Shearing 2003).

It may be argued that non-state security governance in Northern Ireland is not therefore concerned solely with 'safety' in a police-centric sense, but acquires a community meaning in terms of providing a sense of belonging, cooperation and social support as an attribute of the (conflict-related) circumstances in which auspices of policing are embedded (Coleman 1994). Thus, 'shadow policing' may be defined through its representation of a symbolic order in addition to an empirical policing reality (Delanty 2003:46). This was highlighted through the assertion of one community organisation that claimed:

'the vast majority of community groups - 95\%, are able to collaborate together...enable them to reign in their own ambitions about something and say 'so and so does that type of thing better than we do, so they should be the ones [with primacy]. So we [as a network of community groups] have that understanding'.

Such an assertion in relation to socially-informed rules of operation have been supported through research by the Criminal Justice Inspection for Northern Ireland (CJINI) who, in attempting to examine the contributions of the community/voluntary sector to the criminal justice system, have accepted that:

'in broad terms the voluntary and community sector was seen as the most appropriate for social inclusion and support work, including crime prevention, while the state sector was seen as fulfilling legal compliance and enforcement responsibilities (CJINI 2006:13).

But as a note of caution, much of this activity is based upon sectarian lines, clearly not conducive to an overarching public security 'good' for the country (Shirlow and Murtagh 2006).

In taking a step back from attempts to define 'shadow policing', precisely the problem for wider societal and indeed, state acceptance, of non-state policing contributions has been the politics of police reform, as noted above. With the primary focus of policing in Northern Ireland having been shaped by the imperatives of institutional-political reform over the past 15 years, this has effectively distracted 
attention from the unique defining contexts which generated non-state policing in the first place (Rose 1996). Indeed, this police-institutional centrism has remained wedded to the assumption that to 'fix' the police as an organisation is to deal with the wider problems of policing in Northern Ireland - themselves grounded in over 30 years of conflict. This has resulted in the de facto marginalisation of those groups and organisations on both sides who wish to participate in, or pose a challenge to, the centrality of policing by PSNI. As one interviewee stated:

'there are all these organisations, and you can call them what you like, but there is a reluctance...there is a reluctance to let go of some control. And I don't mean you hand over policing [to community groups] wholesale, but to work more with, and give more to community groups and organisations which are already in existence' (community respondent).

Thus, in returning to the concept of 'recoding', the definition of 'shadow policing' is currently that of a marginal, competing or illegitimate activity. On the one hand, it can be argued that such policing contributions have helped to create a more stable societal landscape in which the police-organisational reform process has been able to flourish. Yet on the other hand, 'shadow policing' by virtue of its unique operational circumstances, does not easily fall under 'normal' definitions of policing, the consequence of which has been for such activity in both Loyalist and Republican communities to be simply 'affiliated to some kind of anti-community whose morality, lifestyle or comportment is considered a threat...' (Rose 1996:340).

\section{Delivering shadow policing}

In moving away from definitional issues associated with non-state security governance, it is important to consider 'shadow policing' in terms of the dynamics of its delivery. The authors would argue on the basis of the evidence, understandings of the diverse ways in which policing and security are exercised in the country have been unduly tied to either the explicit crime reduction strategies of the PSNI; or the maintenance of social control by paramilitary actors (Rose and Miller 1992; Feenan 2002). Therefore, the focus of this section shall be to move beyond the association between police work and ontological community understandings of security, to consider the delivery of 'shadow policing' with reference to the etiology of security production (Loader and Walker 2001).

A key reference point in terms of the delivery of 'shadow policing' is with the networked structure of these auspices and providers of security (Martin 2012). 
Across both Loyalist and Republican communities, the variety of groups and bodies in existence to promote local policing do so in a way which is neither explicitly ordered, nor randomly conceived. This structure was most succinctly described by one Loyalist grouping, detailing that:

'what you have in this areas is very good [community] structure which has lots of things underneath it...they would be a good central hub there...[name] will complement the bits that everyone else is doing, filling the gaps, or developing new areas of working which no one else has the time or resources to do'.

Beyond organisational rules and hierarchies, such networks in fact use 'relationships to influence behavior and change minds...are more flexible, less hierarchical and therefore more responsive to...shifts in the environment' (Gilchrist 2004:34). With the basis for membership of a network generally derived from 'interest' rather than strictly geography (except across sectarian divides), it is precisely this fluid, amorphous dynamic which allows non-state policing in the country delivery to have access into, and comprise of, virtually all latent community capacities and spheres of life - and to manage the complexity of potential relations. This was noted by a community representative insofar as:

'in [area] all those dots in that map behind you [points to wall chart with 250 community organisations], I will probably know somebody in every one of those organisations, and there might be ten others [groups] in [area] who will...'

As the basis for a unique form informal intelligence-led policing, such arrangements allow each of the nodes or auspices to develop:

'a detailed local knowledge of places and spaces...rely to a great extent on their personal knowledge of and relationships with local residents, young people and of local groups, and they have the ability to act effectively because they each have a degree of local authority' (Jarman 2006:35).

Further considering delivery of 'shadow policing' as informal policing through knowledge-led approaches, the mediating impact of local communities for social order may also be observed (Foster 1995). With the delivery of non-state policing grounded in local context and need rather than structural, organisational outputs associated with PSNI for example, the delivery of 'shadow policing' is thus part of a broader policing philosophy whereby:

'it makes no sense at all to treat an offender as if he had no family, never went to school or work, never visited the shops... if you ignore the fact the boy who 
broke the window lives in the next street, that his dad drinks in the local pub...who else...can participate in mending...the problems crime has created' (Alternatives 2000 cited in McEvoy et al. 2002:201).

This point was clearly made by a Republican-based organisation involved more holistic approaches to policing and quality of life insofar as:

'we have crèche facilities, after school clubs, young peoples' groups on a range of issues...young men's and women's groups...so we've a finger on the pulse of every aspect of community life. Many people would say this centre is the heartbeat of the community'.

However, in terms of generic notions of the 'public good' of security, it is important not to conceive the delivery such activity as part of any grand 'project' to render alternative policing solutions to entire populations or communities. Rather, the importance of its delivery lies with its tailored, networked ability to mediate the nexus between local security needs and capacities - the aggregation of which across the multitude of actors and organisations across the country has implications for PSNI in terms of their resourcing; and for populations less affected by crime (Shearing and Wood 2003). Thus, to consider the delivery of 'shadow policing' without reference to the nature of its existence or potential wider impact fails to consider the innovative nature of such capacities; assumes the delivery of such policing activity is a purely self-serving process; and that state policing provision is but optional as opposed to lacking in such communities where non-state policing exists (Perry et al. 1976).

From a state perspective, to acknowledge the authority and capacity of nonstate policing is also to 'accept' some aspect of authoritative transfer to what may be conceived as barely accountable auspices of security by PSNI (Loader 2000). In addition, the deep-rooted social, economic and sectarian issues which for so long have remained hidden under the veil of the conflict arguably need to be underpinned by greater - not less - state intervention and support.

But in terms of the foundational security effected through the delivery of 'shadow policing' in mainly working class Loyalist and Republican communities, it is itself predicated upon organised communities, trust, social capital, shared values and relatively low levels of crime. As recounted by one respondent:

'everybody knows everybody. Nothing can happen without someone else knowing. And we have workers like [name] who could tell you the name of every young person in [area] - so it's impossible for anyone to do anything without someone knowing'. 
Interestingly, such embedded, networked community qualities would appear to mitigate factors deemed fatal to the necessary community organising and capacities (such as deprivation and sectarianism) as part of governing their own security affairs (Jones 2007; Matsueda 2006: Nolan et al. 2004). Here, the absence of disorder and community breakdown may be a more useful metric of delivery as opposed to the presence of procedural police metrics which for so long has underpinned state-based thinking on security in the country.

But in terms of 'shadow policing', one outstanding issues which merit attention is motivation for delivery. Related more closely to Republican/Nationalist communities because of the traditional dissociations with state policing apparatus (Mulcahy 2006), the genesis for such activity in the first place derived from the political goals of 'resisting' the state; together with police inability to deliver 'normal' policing set within the counter-terrorism context (Hamilton et al. 1995). However, in the post-ICP era of fully inclusive political support for the PSNI, a question seldom asked relates to the extent to which the delivery of 'shadow policing' remains an incentive to continue with limited contact and engagement between communities and PSNI.

While predating the current all-party support for policing, Ellison and Mulcahy (2001) have noted that mainly Republican/Nationalist communities remained 'satisfied' with the police by virtue of their absence at a local level. Though set within the contemporary context, more recent studies have evidence continuing dissociation between both Republican/Nationalist and Loyalist/Unionist communities - albeit grounded in perceptions of a poor policing service by PSNI rather than politics (Topping 2008a; 2008b; Byrne and Monaghan 2008; Topping and Byrne 2012a). Indeed, it is precisely within such communities where 'shadow policing' remains most active. And while direct correlations between the quality of service by PSNI, post-conflict politics and community reliance upon alternative policing cannot readily be made, the evidence relating to a lack of policing by PSNI in such areas undoubtedly creates a dilemma for communities as to whether they should endure state-police deficits, or simply wait improvements, or enlist alternative forms of security provision despite their potential to damage the 'public good' of state policing (Dupont and Wood 2006:242). This point was captured by a Republican respondent in a 'hard-to-reach' area, stating that: 
'to me, people are phoning us to deal with stuff rather than phoning the police...because we'll find a way of dealing with it. Sometimes people don't see the situation a child is in - they just see the crime and the consequences of it...it's trying to find ways of dealing with it without punishment beatings, or dragging them through the courts...its local knowledge again’.

\section{Co-opting shadow policing?}

Having examined both the contextual and delivery aspects related to non-state security governance in Northern Ireland, the outstanding question of harnessing, or co-opting the latent 'soft power' extant across the country's (mainly) working-class Loyalist and Republican communities remains (Vaughan 2007). At a general level, the authors contend that security governance theory has been relatively underdeveloped on the issue of incorporating, in a practical sense, the operational capacities of alternative policing actors into an overarching state agendas or frameworks (Johnston and Shearing 2003; Martin 2012). In Northern Ireland, this issue has been further complicated through political, paramilitary and state police actors who have monopolised the language and ownership surrounding policing and security more generally. The remainder this section will therefore seek to provide a more nuanced disaggregation of potential avenues for co-opting non-state security provision into practical policing considerations as a challenge to the limiting institutional police narratives which have dominated the post-ICP era (Loader 2000).

The centre of any such debate related to co-opting 'shadow security' capacities must begin with an acknowledgement of the ICPs original vision for developing a regulatory policing, rather than just police system in the country (Topping 2008b). Here, Dupont (2006:107-8) clearly spells out that:

'the selective implementation of the...[ICP] recommendations which abandoned the broader security mandate in favour of more traditional forms of police supervision, makes clear the normative challenges posed by nodal regulation...old patterns represent a force of attraction which is hard to resist'

In addition to what may be observed as 'path dependent' reluctance to diversify policing beyond PSNI (Topping 2008b; Marnoch et al. 2013), this sentiment was captured by one community representative:

if you're going to talk about allowing it [community-based security governance] to exist and to use its strengths and to capitalise on its voice and to use it as a conduit - we have to accept the organic nature of it and accept the fact it is independent...' 
The present research would also point to more subtle issues associated with co-opting ‘shadow policing' provision and according such activities more than an 'unspoken' policing role. On a simple plain, the assimilation, or at least incorporation of organisations and actors into state-centric modes of operation retains the potential to transform community networks and relations into a different (and possibly diminished) set of relations by virtue of new, 'alien' forms of regulation and operating logics. It is somewhat ironic that introducing PSNI into networks of security governance could actually destabilise community relations through the removal of local 'ownership' on local policing matters (Tonkiss and Passey 1999). Thus, precisely how to render non-state contributions more accessible to the police and vice versa without damaging the vitality of local policing efforts is a fundamental issue to be negotiated on local terms rather than those set exclusively by the police or state. Although interestingly, the will for community groups to engage with formal state policing was apparent from interviews insofar as:

'policing can't be left to the police. And I mean, if a local community want to take steps, and real positive steps in order to address various issues in that area, I think it should be encouraged, but it should be done in co-operation with the police...' (community respondent).

More broadly, co-opting non-state actors into programmes of joint action with PSNI must remain alert to the potential added value which may be derived above and beyond traditional police-centric attempts at community engagement (Brogden and Nijhar 2005). Where this can be negotiated within acceptable parameters, there exists the potential (at least for PSNI) to engage not just a community of individuals, but to co-opt a whole spectrum of latent community capital (Dupont 2004). The ancillary benefits of taping into these 'moneyless economies' not only recognises and reinforces the work already being done, but may further enable PSNI to gain access to services, knowledge and capital not otherwise available through the policeinstitutional modes of working (Gilchrist 2004). This was clearly articulated by one respondent who claimed that:

'cops need to take it [local security governing] seriously. Because see anything that you want to know about [area], somebody from [named group] will tell you, and that's who done what to who, when they did it, what they did it with and how they got away - and that's what policing is about'. 
From the research, it was also clear that as part of co-opting non-state security auspices, consideration should also be given to the power which resides in these organisations to attract voluntary compliance within and between populations in terms of both ideological and operational 'buy in' to policing (Shearing 2006). And while this has, to some extent, been informally developed between PSNI and community actors over the past decade (Jarman 2002; 2006; Topping \& Byrne, 2012a), the question of formalising this approach for 'normal' crime and quality of life issues has yet to be fully answered. This was succinctly captured by one group who indicated that:

'the community is only a meaningful concept if people are allowed to organise, associate and articulate collective views. Which means...working through organisations. So if you [PSNI] don't trust or fund or support those organisations, and recognise what they are, you can't deal with the community...'

As a final proposition for co-opting 'shadow policing' into more formal (state) arrangements, the evidence would suggest that community-based policing provision also has the ability to 'level' the asymmetrical landscape of security and policing provision more generally (Stenson, 2005). As part of Braithwaite's contention that security for the 'poor' (or marginal) is the best hope of security for the 'rich' within inequitable societies such as Northern Ireland (2000:231), it was suggested by one community worker that security governance is:

'a long term project. In the short term, it's all the stuff [crime issues] we're dealing with now...This is for a safer, better, stronger community, people representing and supporting each other...this is the future - strong residents' groups, people giving leadership, providing a voice for those that are vulnerable'.

Ultimately, the state of security through the varying combinations of state and 'shadow policing' contribute to the relatively low-crime state status enjoyed by Northern Ireland as a whole (Department of Justice 2012). In this regard, the 'security' aspect of non-state security governance can more robustly be defended as a tangible output set within the country's policing landscape. However, it is the 'governance' (or co-opting) aspect of security governance which, on the basis of the evidence, continues to limit the potential place of non-state others as viable arbiters of policing. 


\section{Conclusion}

In summary, the evidence presented in this paper points to what is a complex picture of 'shadow policing', both in terms of conceiving and delivering policing outside the state; and the relations between community-based auspices of security and (potentially) the state policing apparatus. In many respects, such complexity defies placing the activities of these security others into predefined categories or models of operation - but only where the generation of policing and security is viewed from a central, police-institutional lens. Thus, the current paper has attempted to provide a more nuanced understanding of policing and security across Northern Ireland's Loyalist and Republican communities from the perspective of the locale, the difficult translation of which into more formal policing language should not presuppose viability or legitimacy.

In part, and outside the limiting parameters of police-institutional reform in the country, there may actually be some 'softening' of governmental attitudes to coopting our non-state actors. With the Criminal Justice Review (CJR) of 2000 having excluded schemes involved in community-based security governing by virtue of being peripheral to the formal criminal justice apparatus (CJR 2000: para.9.57), over a decade on the Department of Justice's (DoJ) most recent community safety strategy has provided space to explore the role of community-based contributions to the community safety initiatives (DoJ 2012). Yet in spite of the extensive (and in many cases vital) role of 'shadow policing' as part of the security landscape, to merely 'explore' such contributions is symptomatic of a general sentiment by non-state actors 'that their role in addressing community safety issues had gone un-noticed or unrecognised by statutory organisations, at least at an official level of discourse' (Topping and Byrne 2012a:63).

Across both Loyalist and Republican communities, it is also clear that nonstate security governance in the country occupies a significant 'space', or 'foundational presence' from which other community freedoms and organising flow. In view of the evidence, a relevant course of inquiry at a theoretical and practical level - and especially for areas with conflicted policing arrangements - might be to move beyond security as we currently understand it in police-organisational sense; and look at the freedoms non-state security governance helps generate in terms of education, health and welfare and consider the extent to which 'shadow policing' 
contributes to these 'democratic goods' rather than generating 'security goods' in isolation (Loader and Walker 2006). Indeed, this has significant implications as part of facilitating latent community 'soft power' as a means through which to persuade and influence populations at the bottom of the social, economic, educational and health hierarchies, as well as improve their quality of life (Walklate 2003).

But as the paper has argued, is ultimately those non-state organisations on the ground within working-class Loyalist and Republican communities who act as the guardians of unseen community capital, resilience and safety - the absence of which would render those communities and areas more destabilised than if security and policing was delivered solely by PSNI, regardless of moral, political or policy arguments to the contrary. The issue therefore lies not necessarily with the auspices of 'shadow policing' themselves, but with the state-institutional capacity to accept that Northern Ireland's buoyant, post-conflict society would be less safe and secure without them (Nolan 2012). In attempting to capture 'shadow policing' as a 'trait' of Northern Ireland's post-conflict society, the current status quo may be observed through the lens of one community representative, who simply noted:

'I think it's just madness - here you've got vibrant communities...yet we [as a society] don't see the potential in using those people, using those people to design engagement with the police'. 


\section{References}

Acheson, N., Harvey, B., Kearney, J. and Williamson, A., 2004. Two Paths, One Purpose: Voluntary Action in Northern Ireland, North and South. Dublin: Institute of Public Administration.

Altebeker, A., 2005. The Dirty Work of Democracy. Johannesburg: Jonathon Bell.

Baker, B., 2002. 'Living with Non-State Policing in South Africa: The Issues and Dilemmas', Journal of Modern African Studies, 40 (1), 29-53.

Bayley, D. H., 2008. 'Post-conflict police reform: Is Northern Ireland a model?' Policing, 2 (2), 233-240.

Belfast Telegraph, 2012. Protest Brands PSNI's Drug Fight 'Toothless', 17 ${ }^{\text {th }}$ August, accessed at:

http://www.belfasttelegraph.co.uk/news/local-national/northern-ireland/protestbrands-psnis-drugs-fight-toothless-28782198.html

Black, J., 2000. 'Proceduralizing Regulation: Part I', Oxford Journal of Legal Studies, 20 (4), 597-614.

Braithwaite, J., 2000. 'The New Regulatory State and The Transformation of Criminology’, British Journal of Criminology, 40, 222-238.

Brewer, J., 2001. 'The Growth, Extent and Causes of Crime: Northern Ireland'. In: M. Shaw, ed. Crime and policing in transitional societies seminar report: Johannesburg, KAS, 103-110.

Brogden, M., 2000. 'Burning Churches and Victim Surveys: The Myth of Northern Ireland as Low-Crime Society’, Irish Journal of Sociology, 10, 27-48.

Brodgen, M. and Nijhar, P., 2005. Community Policing: National and International Approaches. Cullompton: Willan Publishing

Brunger, M., 2011. From Police to Policing: Policing Reform in Northern Ireland and the Vision of Partnership. Thesis (PhD . Queen's University Belfast, Northern Ireland.

Byrne, J. and Monaghan, L., 2008. Policing Loyalist and Republican Communities. Belfast: Institute for Conflict Research.

Campbell, C., Ni Aolain, F. and Harvey, C., 2003. 'The Frontiers of Legal Analysis: Reframing the Transition in Northern Ireland', Modern Law Review, 66 (3), 317-345.

Coleman, J., 1994. The Foundations of Social Theory. London: The Belknap Press of Harvard University Press.

Crawford, A., 1995. 'Appeals to Community Crime Prevention', Crime, Law and Social Change, 22, 97-126. 
Criminal Justice Inspection Northern Ireland, 2006. Added Value? A Review of the Voluntary and Community Sectors' Contribution to the Northern Ireland Criminal Justice System. Belfast: Criminal Justice Inspection Northern Ireland

Criminal Justice Inspection Northern Ireland, 2012. Policing with the Community: A Follow Up Review of Inspection Recommendations. Belfast: Criminal Justice Inspection Northern Ireland

Criminal Justice Review Group, 2000. Review of the Criminal Justice System in Northern Ireland. A Guide. Belfast: The Stationary Office.

Delanty, G., 2003. Community. London: Routledge.

Department of Justice, 2012. Building Safer, Shared and Confident Communities: A Community Safety Strategy for Northern Ireland 2012-2017. Belfast: Department of Justice.

Dupont, B., 2004. 'Security in the Age of Networks', Policing and Society, 14 (1), 7691

Dupont, B., 2006. 'Power Struggles in the Field of Security: Implications for Democratic Transformation'. In: J. Wood and B. Dupont, B., eds. Democracy, Society and the Governance of Security. Cambridge: Cambridge University Press, 86-110.

Dupont, B., Grabosky, P. and Shearing, C., 2003. 'The Governance of Security in Weak and Failing States’, Criminal Justice, 3 (4), 331-349.

Dupont, B. and Wood, J., 2006. 'Conclusion: The Future of Democracy'. In J. Wood, and B. Dupont, eds. Democracy, Society and the Governance of Security. Cambridge: Cambridge University Press, 241-248.

Dwyer, C., 2012. 'Expanding DDR: The Transformative Role of Former Prisoners in Community-based Reintegration in Northern Ireland', The International Journal of Transitional Justice, 6, 274-295.

Ellison, G., 2000. 'Reflecting all Shades of Opinion' Public Attitudinal Surveys and the Construction of Police Legitimacy in Northern Ireland', British Journal of Criminology, 40, 88-111.

Ellison, G., 2007. 'A blueprint for democratic policing anywhere in the world: Police reform, political transition, and conflict resolution in Northern Ireland', Police Quarterly, 10 (3), 243-269.

Ellison, G. and Martin, G., 2000. 'Policing, Collective Action and Social Movement Theory: The Case of the Northern Ireland Civil Rights Campaign', British Journal of Sociology, 51 (4), 681-699.

Ellison, G. and Mulcahy, A., 2001. 'Policing and Social Conflict in Northern Ireland', Policing and Society, 11, 243-258. 
Ellison, G., and O‘Rawe, M., 2010. 'Security Governance in Transition: The Compartmentalising, Crowding Out, and Corralling of Policing and Security in Northern Ireland', Theoretical Criminology, 14 (1), 1-27.

Feenan, D., 2002. 'Community Justice in Conflict: Paramilitary Punishment in Northern Ireland'.: D. Feenan, ed. Informal Criminal Justice. Aldershot: Ashgate Publishing, 41-60.

Foster, J., 1995. 'Informal Social Control and Community Crime Prevention', British Journal of Criminology, 35 (4), 563-583.

Frampton, M., 2010. The Return of the Militants: Violent Dissident Republicanism. London: ICSR

Accessed at:

http://www.icsr.info/publications/papers/1289498383ICSR_TheReturnoftheMilitants Report.pdf 5/12/2010

Garland, D., 2001. The Culture of Control: Crime and Social Order in Contemporary Society. Oxford: Oxford University Press.

Gilboy, J., 1998. 'Compelled Third - Party Participation in the Regulatory Process: Legal Duties, Culture, and Noncompliance’, Law and Policy, 20 (2),135-155.

Gilchrist, A., 2004. The Well Connected Community. Bristol: Policy Press.

Grabosky, P., 1992. 'Law Enforcement and the Citizen: Non-Governmental Participation in Crime Prevention and Control', Policing and Society, 2, 249-271.

Granovetter, M., 1983. 'The Strength of Weak Ties: A Network Theory Revisited', Sociological Theory, 1, 201-233.

Hamilton, A., Moore, L. and Trimble, T., 1995. Policing a Divided Society: Issues and Perceptions in Northern Ireland. Coleraine: Centre for the Study of Conflict.

Hayes, B. and McAllister, I., 2005. 'Public Support for Political Violence and Paramilitarism in Northern Ireland and the Republic of Ireland', Terrorism and Political Violence, 17, 599-617.

Hughes, G., 2007. The Politics of Crime and Community. New York: Palgrave Macmillan.

Jarman, N., 2002. Managing Disorder: Responding to Interface Violence in North Belfast. Belfast: Community Development Centre/Office of the First and Deputy First Minister.

Jarman, N., 2006. 'Peacebuilding and Policing - The Role of Community Based Initiatives', Shared Space: A Research Journal on Peace, Conflict and Community Relations in Northern Ireland, 3, 31-44 
Johnston, L. and Shearing, C., 2003. Governing Security: Explorations in Policing and Justice. London: Routledge.

Jones, T., 2007. 'The Governance of Security: Pluralisation, Privatisation, and Polarisation in Crime Control'. In M. Maguire, R. Morgan and R. Reiner eds. The Oxford Handbook of Criminology. $4^{\text {th }}$ ed. Oxford: Oxford University Press, 841-865

Kempa, M. and Shearing, C., 2002. 'Microscopic and Macroscopic Responses to Inequalities in the Governance of Security: Respective Experiments in South Africa and Northern Ireland', Transformation, 49, 25-54

Lea, J., 2002. Crime and Modernity: Continuities in Left Realist Criminology. London: Sage Publications.

Loader, I., 2000. 'Plural Policing and Democratic Governance', Social and Legal Studies, 9 (3), 323-345.

Loader, I. and Walker, N., 2001. 'Policing as Public Good: Reconstituting the Connections between Policing and the State', Theoretical Criminology, 5 (1), 9-35.

Loader, I. and Walker, N., 2006. 'Necessary Virtues: The Legitimate Place of the State in the Production of Security'. In: J. Wood and B. Dupont eds. Democracy, Society and the Governance of Security. Cambridge: Cambridge University Press, 165-195.

Knox, C., 2002. 'See No Evil, Hear No Evil' Insidious Paramilitary Violence in Northern Ireland’, British Journal of Criminology, 42 (1), 164-185.

Lundy, P., 2011. 'Paradoxes and Challenges of Transitional Justice at the 'Local' level: Historical Enquiries in Northern Ireland', Contemporary Social Science, 6(1), 89-106.

Lyness, D., McEnarney, R. and Carmichael, M., 2004. Digest of Information On the Northern Ireland Criminal Justice System. Belfast: NIO.

McDonald, H., 2012. 'Police Say 1200 Officers Have Been Hurt in Northern Ireland Riots in Seven Year', The Guardian $4^{\text {th }}$ September, Accessed at:

http://www.guardian.co.uk/uk/2012/sep/04/police-hurt-northern-ireland-riots

McEvoy, K., Gormally, B. and Mika, H., 2002. 'Conflict, Crime Control and the 'Re'-Constitution of State-Community Relations in Northern Ireland'. In G. Hughes, E. McLauglin and J. Muncie eds. Crime Prevention and Community Safety: New Directions. London: Sage Publications, 182-212

McLoughlin , P. and Miller , R. ( 2006 ), 'Whatever You Say, Say Nothing’: The Issue of " Macro-Context " in the Construction of a Catalogue and Archive of Qualitative Material on the Northern Ireland Conflict', Methodological Innovations Online, 1(2), available at:

http://erdt.plymouth.ac.uk/mionline/public_html/viewarticle.php?id=30\&layout=html (accessed 20/6/2008) 
Marks, M. and Goldsmith, A., 2006. 'The State, the People and Democratic Policing: The Case of South Africa'. In: J. Wood and B. Dupont eds. Democracy, Society and the Governance of Security. Cambridge: Cambridge University Press, pp.139-164

Marnoch, G. Topping, J. R. and Boyd, G., 2013. 'Explaining the Pattern of Growth in Strategic Actions Taken by Police Services During the New Labour Years: An Exploratory Study of an English Police Service' Policing and Society (forthcoming)

Martin, J., 2012. 'Informal Security Nodes and Force Capital', Policing and Society, 1-19 (i-First article) DOI:10.1080/10439463.2012.671821

Mason, J., 1996. Qualitative Researching. London: Sage Publications.

Matsueda, R., 2006. 'Differential Social Organization, Collective Action and Crime', Crime, Law and Social Change, 46, 3-33.

Monaghan, R., 2004. 'An imperfect peace: Paramilitary 'punishments' in Northern Ireland. Terrorism and Political Violence, 16 (3), 439-46.

Morrissey, M. and Pease, K., 1982. 'The Black Criminal Justice System in West Belfast', The Howard Journal, 21, 159-166.

Morrow, D., 2006. 'Sustainability in a Divided Society: Applying Social Capital Theory to Northern Ireland', Shared Space: A Research Journal on Peace, Conflict and Community Relations in Northern Ireland, 2, 63-79.

Mulcahy, A., 2006. Policing in Northern Ireland: Conflict, Legitimacy and Reform. Devon: Willan Publishing.

Nolan, P., 2012. Northern Ireland Peace Monitoring Report Number One. Belfast: Community Relations Council for Northern Ireland.

Nolan, J., Conti, N. and McDevitt, J., 2004. 'Situational Policing: Neighbourhood Development and Crime Control', Policing and Society, 14 (2), 99-117.

Northern Ireland Council for Voluntary Action, 2005. State of the Sector IV. Belfast: NICVA.

O’Mahony, D., Geary, R., McEvoy, K. and Morison, J., 2000. Crime, Community and Locale: The Northern Ireland Communities Crime Survey. Aldershot, Ashgate Publishing Company.

O’Malley, P., Wier, L. and Shearing, C., 1997. 'Governmentality, Criticism and Politics', Economy and Society, 26 (4), 501-517.

O’Rawe, M., 2003. 'Transitional Policing Arrangements in Northern Ireland: The Can't and Won't of Change Dialect', Fordham International Law Journal, 22, 10151073. 
Office of the Oversight Commissioner, 2006. Overseeing the Proposed Revisions for the Policing Services in Northern Ireland Report 18. Belfast: Office of the Oversight Commissioner.

Office of the Oversight Commissioner, 2007. Overseeing the Proposed Revisions for the Policing Services of Northern Ireland Report 19. Belfast: Office of the Oversight Commissioner .

Perry, R., Gillespie, D. and Parker, H., 1976. Social Movements and Local Community. Sage Research Papers in the Social Sciences (Social Ecology of the Community Series, No. 90-037). Beverly Hills and London: Sage Publications.

Police Service of Northern Ireland, 2012. Recorded crime and clearances $1^{\text {st }}$ April 219 - 31 ${ }^{\text {st }}$ March 2012 Annual Statistical Report.

Accessed at:

http://www.psni.police.uk/index/updates/updates_statistics.htm

Putzel, J., 1997. 'Policy Arena Accounting for the 'Dark Side' of Social Capital', Journal of International Development, 9 (7), 939-949.

Report of the Independent Commission on Policing for Northern Ireland, 1999. A New Beginning: Policing in Northern Ireland. Belfast: HMSO.

Rose, N., 1996. 'The Death of the Social? Re - Figuring the Territory of Government', Economy and Society, 25 (3), 327-356.

Rose, N. and Miller, P., 1992. 'Political Power Beyond the State: Problematics of Government', British Journal of Sociology, 43 (2), 173-205.

Ryder, C., 1997. The RUC 1922-1997 A Force Under Fire. London: Mandarin Paperbacks.

Shaw, M. and Shearing, C., 1998. 'Reshaping Security: An examination of the Governance of Security in South Africa', African Security Review, 7 (3), 3-12.

Shearing, C., 2000. 'A New Beginning' for Policing', Journal of Law and Society, 27 (3), 386-393.

Shearing, C., 2001. 'The Changing Face of the Governance of Security and Justice'. In M. Amir and S. Enstein eds. Policing, Security and Democracy: Theory and Practice. USA: Office of International Criminal Justice, 99-114.

Shearing, C., 2004. 'Thoughts on Sovereignty', Policing and Society, 14 (1), 5-12.

Shearing, C., 2006. 'Reflections on the Refusal to Acknowledge Private Governments', In: J. Wood and B. Dupont eds. Democracy, Society and the Governance of Security. Cambridge: Cambridge University Press, 11-32.

Shearing, C. and Wood, J., 2003. 'Governing Security for Common Goods', International Journal of the Sociology of Law, 31 (3), 205-255. 
Shirlow, P. and Murtagh, B., 2006. Belfast: Segregation, Violence and the City. London: Pluto Press.

Shirlow, P., Graham B., McEvoy, K., Oh Adhmaill, F. and Purvis, D., 2005. Politically Motivated Former Prisoner Groups: Community Activism and Conflict Transformation. A Research Report Submitted to the Community Relations Council.

Stenson, K., 2005. 'Sovereignty, Biopolitics and the Local Government of Crime in Britain’, Theoretical Criminology, 9 (3), 265-287.

Tonkiss, F. and Passey, A., 1999. 'Trust, Confidence and Voluntary Organisations: Between Values and Institutions’, Sociology, 33 (2), 257-274.

Topping, J. R., 2008a. 'Community Policing in Northern Ireland: A Resistance Narrative', Policing and Society, 18 (4), 377-398.

Topping, J. R., 2008b. 'Diversifying From Within: Community Policing and the Governance of Security in Northern Ireland', British Journal of Criminology, 48 (6), 778-797.

Topping, J. R. (2009) Beyond the Patten Report: The Governance of Security in Policing with the Community. Thesis (PhD), University of Ulster.

Topping, J., 2013. Northern Ireland Neighbourhood Watch: Participatory Mapping and Socio Demographic Uptake. Institute for Research in Social Sciences, available at:

http://www.nipolicingboard.org.uk/es/ni_neighbourhood_watch_8211_gis_mappi ng.pdf

Topping, J. R. and Byrne, J., 2012a. Community Safety: A Decade of Development, Delivery, Challenge and Change in Northern Ireland. Belfast: Belfast Conflict Resolution Consortium.

Accessed at:

http://www.bcrc.eu/userfiles/Community\%20Safety\%20\%20A\%20Decade\%20of\%20 Change\%20in\%20NI.pdf

Topping, J. R. and Byrne, J., 2012b. 'Paramilitary Punishments in Belfast: Policing Beneath the Peace', Behavioral Sciences of Terrorism and Political Aggression, 4 (1), 41-59.

Undheim, T., 2003. 'Getting Connected: How Sociologists Can Access the High Tech Elite', The Qualitative Report, Accessed at: http://www.nova.edu/ssss/QR/QR81/undheim.pdf, accessed 28 January 2006

Van Dijk, J.J.M., Mayhew, P. and Killias, M., 1990. Experiences of Crime Across the World: Key Findings from the 1989 International Crime Survey. Denenter: Kluwer Law and Taxation. 
Vaughan, B., 2007. 'The Provision of Policing and the Problem of Pluralism', Theoretical Criminology, 11 (3), 347-366.

Walklate, S., 2003. 'I Can’t Name any Names but What's-his-Face up the Road will sort it Out': Communities and Conflict Resolution'. In: K. McEvoy and T. Newburn eds. Criminology, Conflict Resolution and Restorative Justice. Basingstoke: Palgrave MacMillan, 208-222.

Wood, J., 2004. 'Culture Change in the Governance of Security', Policing and Society, 14 (1), 31-48.

Young, J., 1999. The Exclusive Society. London: Sage Publications.

Zedner, L., 2003. 'Too Much Security?', International Journal of the Sociology of Law, 31 (3), 155-18.

Zedner, L., 2009. Security. London: Routledge

\section{Acknowledgements}

We gratefully acknowledge the permission granted by the Belfast Conflict Resolution Consortium to use the data from the original research report carried out by the authors. 